O eixo e a roda, Belo Horizonte, v. 24, n. 2, p. 49-69, 2015

\title{
Indivíduo e sociedade no romance Triste fim de Policarpo Quaresma
}

\section{Individual and society in the novel The sad end of Policarpo Quaresma}

Irenísia Torres de Oliveira

Universidade Federal do Ceará (UFC), Fortaleza, Ceará, Brasil.

irenisia@gmail.com

Resumo: Este artigo analisa as relações entre indivíduo e sociedade no romance Triste fim de Policarpo Quaresma, de Lima Barreto, levando em consideração as reflexões de Ian Watt e Roberto Schwarz sobre o romance realista; investiga inicialmente a constituição de Policarpo como um indivíduo no romance, desde algumas condições concretas de relativa autonomia e liberdade até a combinação ideológica que fundamenta variadamente suas ações (individualismo liberal, nacionalismo e racionalismo positivista); examina também as relações sociais que recolocam Policarpo no chão da vida concreta, a cada ação patriótica, e conclui que o romance propõe uma interpretação do problema nacional: a inexistência no Brasil de uma nação como projeto coletivo.

Palavras-chave: Triste fim de Policarpo Quaresma; Lima Barreto; romance.

Abstract: This article analyses the relationships between individual and society in This article analyses the relationship between individual and society in Lima Barreto's novel The sad end of Policarpo Quaresma, taking into account considerations by Ian Watt and Roberto Schwarz on the realist novel; it investigates initially the constitution of Policarpo 
as an individual in the novel, from some concrete conditions of relative autonomy and liberty to the ideological combination on which his actions are variedly based (liberal individualism, nationalism and positivist rationalism); it examines also the relationships that situate Policarpo on the ground of concrete life, at each patriotic action, and concludes that the novel proposes an interpretation of a national problem: the inexistence in Brazil of the collective project of a nation.

Keywords: The sad end of Policarpo Quaresma; Lima Barreto; novel.

Recebido em 22 de junho de 2015. Aprovado em 05 de agosto de 2015.

\section{Romance e experiência individual}

No livro $A$ ascensão do romance, Ian Watt procura caracterizar o romance como um gênero novo, que teria aparecido pela primeira vez no século XVIII na Inglaterra. Aceita a proposição dos historiadores do romance de que a característica fundamental da nova narrativa era o realismo, mas propõe pensar esse traço distintivo numa perspectiva histórico-filosófica mais ampla. Para começar, lembra que o realismo do romance era moderno, ligado aos particulares da experiência, em contraposição ao medieval, que se orientava para os universais do espírito. O moderno realismo, com origem em Descartes e Locke, tinha como princípio que o indivíduo podia descobrir a verdade por meio dos sentidos. Entretanto, a ideia de um mundo real apreendido por uma percepção verdadeira ainda não especificava suficientemente o realismo literário, porque essa "ingenuidade metodológica" sempre estivera mais ou menos presente em toda a literatura. A importância do realismo filosófico para o romance era de ordem mais geral: envolvia uma postura, um método e um tipo de problema novos. A postura dessa nova forma de pensar era "crítica, antitradicional e inovadora"; o método consistia "no estudo dos particulares da experiência por um pesquisador individual", supostamente dotado de capacidade de discernimento e desobrigado em relação à tradição; e o problema central era a "natureza da correspondência entre palavras e realidade." (WATT, 1990, p. 14). 
O romance realista seria a expressão na literatura da concepção que se apresentara em Descartes "da verdade como questão inteiramente individual". Ele configurava literariamente a "reorientação individualista e inovadora" que o pensamento e o conhecimento, ou seja, a filosofia e a ciência vinham assumindo. Tal processo incluía também uma mudança de valores. $\mathrm{O}$ critério de julgamento da qualidade das obras passava da "concepção de decoro derivada dos modelos aceitos" para a de fidelidade à experiência individual.

Para incorporar a percepção individual da realidade e manter-se fiel a uma experiência particular, a ficção narrativa tivera de passar por mudanças significativas. O romance abandonara convenções e enredos tradicionais e aplicara-se à particularização dos elementos narrativos: a individualização de personagens, a especificação de tempo e espaço e a adequação da linguagem às situações. A intenção era oferecer "um relato completo e autêntico da experiência humana." (WATT, 1990, p. 31).

A retomada do estudo de Watt neste artigo para um romance de Lima Barreto deve-se a que nosso autor, nos primeiros anos do século XX no Brasil, incorpora fortemente a perspectiva da experiência individual e de uma maneira - individualmente comprometida - que não se verificara ainda no Brasil. Lúcia Miguel Pereira afirma que "Lima Barreto, como Machado de Assis, fala exclusivamente em termos de ficção, é através das suas criaturas que interroga a existência." (PEREIRA, 1988, p. 275). Entre essas criaturas, pode-se dizer que as que terão maior valor heurístico em seus romances, maior poder de "interrogação da existência", são as que se destacam como indivíduos, pela liberdade, autonomia e consciência de si. Mesmo Policarpo Quaresma, que se ressente inicialmente da mania patriótica, uma forma de alienação de si, possui grande autonomia e liberdade para afirmar suas convicções, percorrer uma trajetória variada e no final chegar a uma consciência de si e do mundo. Graças à ação desse indivíduo, o romance faz a crítica do patriotismo ufanista e desmascara a realidade do país na Primeira República, marcada pelo latifúndio, o coronelismo e o autoritarismo. A história de Policarpo explora, como Watt descreve, o problema das relações entre palavras e realidade, expondo-as à crítica a partir da ação de uma figura individual.

Para Roberto Schwarz, os inícios do romance no Brasil, no século XIX, são relevantes tanto para se pensar as formas históricas do gênero como as relações dele com a sociedade que se propõe representar. As formas do romance realista europeu não seriam modelos repetíveis 
em qualquer circunstância, mas estariam profundamente ligadas a um tipo específico de sociedade, predominantemente organizada em bases liberais. Essa visão corrobora o argumento de Watt de que o romance, coerente com sua preferência pela experiência individual, tendia a afastar modelos, convenções e enredos tradicionais (pelo visto, não apenas os da tradição clássica, mas os modelos mesmo de romances que se consolidavam na Europa). Escritores ingleses e franceses tinham criado um "instrumento de descoberta e interpretação" das sociedades burguesas em que viviam (CANDIDO, 2007, p. 429-437). De acordo com Schwarz, tinha sido o enredo baseado no conflito entre amor e dinheiro, sentimento e carreira, vocação e ganha-pão que revolvera as entranhas da sociedade liberal burguesa nos romances realistas do século XIX. Entretanto, no Brasil, a mesma articulação formal não atingia o cerne das relações e problemas do país e ainda trazia dificuldades de composição para os romances nacionais. Mesmo numa das melhores obras de José de Alencar, Senhora, as ideias oscilavam de uma situação narrativa para outra: ora valiam, ora não valiam; ora pesavam, ora não pesavam; ora obrigavam, ora desobrigavam; ora apareciam, ora desapareciam, sem que a composição problematizasse "o sistema de suas modificações". Se o novo tipo de problema tratado pelo romance, por meio do realismo moderno, era a "natureza da correspondência entre palavras e realidade", então esse caráter errático das ideias no romance certamente dificultava a construção de uma narrativa que incorporasse desde a forma o sistema das relações sociais no Brasil. A "natureza" da relação entre ideias e realidade, que no romance inglês e francês se revelava pelo conflito, precisava de um instrumento diferente no Brasil para se relevar; aí onde entravam as soluções encontradas por Machado de Assis (SCHWARZ, 2000).

O conflito no romance realista europeu normalmente estava relacionado aos desejos e ambições dos indivíduos. A sociedade revelava seus mecanismos no atrito com eles, na medida em que lhes negava a realização de seus intentos ou em que os obrigava a se modificarem - a se endurecerem ou corromperem - a fim de conseguir seus objetivos. Esse tipo de enredo no Brasil, onde predominavam o favor e as relações de dependência, não conseguia penetrar de maneira mais ampla e aguda os meandros da sociedade brasileira, uma vez que a ação dos indivíduos, que desencadeava o conflito, constituía uma excentricidade e não a lógica de um modo de viver.

Podemos pensar em algumas explicações para que essa configuração - baseada no indivíduo e no conflito - tenha reaparecido 
de forma tão marcante no romance de Lima Barreto. Ela correspondeu, por parte do autor, a uma apreensão problemática e a uma condenação profunda da sociedade em que viveu. E exigiu que ele tivesse autoconfiança suficiente e independência em relação ao meio para romper com a literatura dominante no Rio de Janeiro. É verdade que ele buscou apoio numa literatura de maior prestígio, a europeia, mas romper com o meio mais imediato não era trivial. Requeria uma motivação forte e confiança no próprio julgamento, o que pressupunha uma visão individualista sobre a tradição e sobre si mesmo. $\mathrm{O}$ autor viveu em uma geração que se formou no período imediatamente posterior à abolição, num momento ao mesmo tempo de triunfo liberal e efervescência positivista. Lima Barreto frequentara o apostolado de Teixeira Mendes na adolescência, sem grande conviçcão, e tivera muito cedo, a partir dali, contato com obras da filosofia ocidental. Ele lê Descartes na época com grande interesse e retém da leitura uma lição antipositivista: em vez de colher do método a certeza na ciência, entusiasma-se pela dúvida sistemática. (BARBOSA, 1988, p. 61-65). A leitura das obras de Descartes, que assentara todo o conhecimento numa prévia consciência de si, daria ao rapazinho meio isolado e inadaptado até entre a família um ponto de apoio intelectual independente do meio. Desde o diário, passando pelas crônicas, até os contos e romances, o autor faria o exercício de construção de si e do mundo, a partir de um percurso individual e de uma postura crítica, que ele definiria como "a tentação danada da analogia" e "o veneno da análise" (BARRETO, 1956c, p. 110). Quando resolveu escrever romances e passou a estudar com afinco os modelos europeus, encontrou neles a reiteração literária dessa forma de pensar e conhecer, baseada no ponto de vista e na experiência individual. A possibilidade de dar curso a essa visão das coisas aponta uma incipiente possibilidade de autonomização civil e intelectual entre as classes médias. Lima Barreto retoma o romance europeu não mais absorvido pela tarefa de criar positivamente o "romance brasileiro" e com ele, por que não dizer, o próprio país, mas numa atitude abertamente problemática em relação à sociedade e ao país. O romance era para ele, portanto, um instrumento com que se propunha tratar os problemas que percebia e o angustiavam, sentidos concomitantemente como seus, particulares, e como de todos, gerais. ${ }^{1}$

\footnotetext{
${ }^{1}$ Pensando as condições sociais de surgimento do romance na sociedade liberal burguesa, Lucien Goldmann formula como hipótese "a ação convergente de quatro fatores": 1)
} 
Em Triste fim de Policarpo Quaresma é uma trajetória individual que dá acesso aos males do país. O nacionalismo do protagonista, mesmo sendo uma ideologia de grupo, não impede que ele se apresente no romance como um indivíduo. Policarpo preenche certos requisitos de autonomia e liberdade que compõem a figura moral do indivíduo moderno. ${ }^{2} \mathrm{O}$ patriotismo o aliena da realidade, mas não impõe que ele se agregue ou pertença a um grupo. Ao contrário, a mania patriótica até o afasta de seus colegas da repartição, que o respeitam e consideram, por um lado, mas o ridicularizam e o evitam, por outro. Policarpo teria algo do indivíduo-fora-do-mundo identificado pelo antropólogo Louis Dumont em sociedades tradicionais. ${ }^{3}$ Também segundo esse autor, não haveria contradição, mas reciprocidade entre nacionalismo e individualismo:

Na realidade, a nação, no sentido preciso e moderno do termo, e o nacionalismo - distinto do simples patriotismo - estão historicamente vinculados ao individualismo como valor. A nação é precisamente o tipo de sociedade global correspondente ao reino do individualismo como valor. Não só ela o acompanha historicamente, mas a interdependência entre ambos impõe-se, de sorte que se pode dizer que a nação é a

introjeção da predominância do valor de troca, ou da categoria da mediação, sobre o valor de uso (dinheiro e prestigio social como valores absolutos, não mediações); 2) subsistência de indivíduos problemáticos, cujos pensamentos e sentimentos continuavam orientados pelos valores qualitativos; 3 ) "um descontentamento afetivo não conceptualizado, uma aspiração afetiva visando diretamente aos valores qualitativos" surgidos "no conjunto da sociedade, ou apenas, talvez, entre as classes médias, em cujo seio se recruta a maior parte dos romancistas"; e 4) o conjunto de valores do individualismo, ligados à concorrência no mercado (liberdade, igualdade, propriedade etc.) (GOLDMANN, 1976, p. 21-23).

2 'Assim, quando falamos de 'indivíduo', designamos duas coisas ao mesmo tempo: um objeto fora de nós e um valor. [...] de um lado, o sujeito empírico que fala, pensa e quer, ou seja, a amostra individual da espécie humana, tal como a encontramos em todas as sociedades; do outro, o ser moral independente, autônomo e, por conseguinte, não-social, portador dos nossos valores supremos, e que se encontra em primeiro lugar em nossa ideologia moderna do homem e da sociedade." (DUMONT, 1985, p. 37).

${ }^{3}$ Louis Dumont cunhou essa expressão num estudo sobre a Índia: "A partir dele [do desenvolvimento indiano], podemos formular a hipótese seguinte: se o individualismo deve aparecer numa sociedade tradicional, do tipo holista, será em oposição à sociedade e como uma espécie de suplemento em relação a ela, ou seja, sob a forma de indivíduofora-do-mundo." Para o antropólogo, o individualismo teria começado, assim, no ocidente (DUMONT, 1985, p. 38-39). 
sociedade global composta de pessoas que se consideram indivíduos." (DUMONT, 1985, p. 21)

Assim como Policarpo se considera vivendo em uma nação de determinado tipo, ele também se imagina como um indivíduo com certos direitos e prerrogativas de ação. O objetivo deste ensaio é analisar o individualismo de Policarpo, que o credencia, em certo modelo de romance, a expor os problemas do país com base em sua experiência individual.

\section{Autonomia e liberdade ou as condições da ação individual}

O enredo do romance Triste fim de Policarpo Quaresma é bastante conhecido. O major Quaresma, funcionário burocrático da Secretaria da Guerra, é o patriota obcecado que um dia decide agir para tornar realidade o que considera as grandes potencialidades de seu país. Com renovado vigor revolucionário, e de decepção em decepção, o herói vaise aprofundando nos problemas brasileiros até ser condenado à morte.

As condições que Policarpo tem no romance, de refletir, planejar e agir para colocar suas ideias em prática são uma novidade na literatura brasileira. Se olharmos um pouquinho para trás, para o âmbito limitado das personagens de classe média nos romances realistas do século XIX no Brasil, a desenvoltura de Policarpo impressiona. Quaresma estaria aproximadamente no mesmo extrato social do Sr. Lemos, do romance Senhora, de José de Alencar, ou de Luís Garcia, personagem de Machado de Assis.

Mesmo tendo uma intenção satírica, o romance se constrói em bases realistas e insere a personagem em condições concretas. Policarpo é um funcionário público, um homem sem ambições pessoais, desinteressado de cargos e que vive no seu próprio mundo, uma vasta biblioteca particular. O emprego e outros rendimentos lhe permitem levar uma vida financeiramente estável, gozar de certa consideração social entre os vizinhos e colegas e adquirir razoável ilustração. Não é casado, não tem filhos e vive com uma velha irmã solteira que, longe de significar um peso, é na verdade o esteio de uma situação doméstica tranquila. $\mathrm{O}$ tema da ascensão social, que tinha sido o problema central do romance anterior de Lima Barreto, o Recordações do escrivão Isaías Caminha, aparece agora de maneira secundária.

No Triste fim..., as possibilidades de ascensão social estão relacionadas ao arrivismo e à competição por cargos na máquina do 
Estado republicano. Os homens jovens ambicionam tornar-se doutores, dadas certas condições familiares ou relações de proteção, para se candidatarem a casamentos vantajosos e a cargos públicos. Esse é o caminho normal da ascensão social no romance, embora apareçam também outras situações menos comuns, como a do compadre italiano de Policarpo, que enriquece pelo comércio. Mas, mesmo nesse caso, a fortuna só ganha foco no romance ao permitir a Olga, a afilhada de Quaresma, comprar um marido doutor, um médico charlatão e arrivista. Percebe-se ainda nesse episódio que a família tradicional, ligada à posse da terra, está fora. O caminho da ascensão já acontecia numa relação entre novos-ricos e doutores, embora continuasse visando a nomeações para cargos públicos.

Policarpo não participa desse jogo, que acontece ao seu redor e envolve as personagens e os cenários de classe média do romance. As relações dele com o mundo de obrigações em volta, quando existem, são tênues ou episódicas: ele dá uma ajuda financeira inicial ao compadre, que depois enriquece; suas manias patrióticas em torno do folclore e da modinha são aproveitadas pelo vizinho para impulsionar o casamento das filhas; o requerimento enviado ao Congresso provoca inveja nos colegas de repartição. Ele mesmo, porém, não se envolve nas malhas das relações e obrigações, mantendo-se à parte do jogo imediato de interesses sociais.

O grande interesse de Quaresma não é pessoal, mas patriótico. Seu afeto e sua inteligência voltam-se inteiramente para a ideia da Pátria: "Não fora o amor comum, palrador e vazio; fora um sentimento sério, grave e absorvente." (BARRETO, 1956b, p. 32). Essa ideia fixa, que concentra todas as energias e motivações do protagonista, é o que o individualiza e o separa dos demais. A obsessão, que restringe seu interesse à Pátria, também pressupõe certa folga. A liberdade de abraçar uma ideia obsessivamente não deixa de ser uma espécie de autodeterminação, ainda que, num segundo momento, o sujeito se aliene à ideologia.

O nacionalismo conduz Policarpo ao militarismo. Ele tenta inicialmente ser militar, mas, depois de dispensado pela junta de saúde, opta por se tornar funcionário do Ministério da Guerra: "No meio de soldados, de canhões, de veteranos, de papelaria inçada de quilos de pólvora, de nomes de fuzis e termos técnicos de artilharia, aspirava diariamente aquele hálito de guerra, de bravura, de vitória, de triunfo, que é bem o hábito da Pátria." (BARRETO, 1956b, p. 33). Note-se que Policarpo tem uma pequena margem para se manter fiel às suas 
inclinações. Não podendo ser militar, como queria inicialmente, tem a opção de ser funcionário da burocracia militar e permanecer no ambiente com o qual se identifica.

Outra característica de Policarpo é ser extremamente metódico. Chega todos os dias em casa às quatro e quinze da tarde, "como se fosse a aparição de um astro, um eclipse.” (BARRETO, 1956b, p. 27). Mesmo nas férias, seguia os horários de refeição dos dias de trabalho, para não perder "seus hábitos burocráticos". O método está ligado à vida burocrática, de acordo com o romance, e não à disciplina militar. O temperamento obsessivo combinava com o trabalho burocrático, de maneira que a rotina não limitava propriamente sua individualidade, mas funcionava também como autolimitação, a julgar pela postura das férias, quando não teria obrigação de seguir os mesmos horários e ainda assim decide mantê-los. A autodisciplina é uma forma de domínio de si mesmo e, portanto, também uma componente de individualismo.

$\mathrm{O}$ amor verdadeiro pelos livros constituía nele mais um fator de individuação: primeiro, porque o diferenciava e isolava dos vizinhos, para quem livros seriam apropriados apenas para doutores; segundo, porque o aliena da realidade em volta. Autodidata, na solidão de seu gabinete, Policarpo conhecia tudo rigorosamente dos livros, sendo um erudito no sentido estrito do termo. Sua própria individualidade (o que ele imaginava ser e o lugar que pensava ocupar no mundo), bem como seu nacionalismo e as noções modernas introjetadas, eram realidades livrescas. O choque entre o pensamento abstrato (haurido dos livros) e a realidade brasileira estrutura o livro do começo ao fim.

O romance atribui certas características ao protagonista que reforçam a individuação (implicando uma boa dose de isolamento) e lhe garante as condições nas quais pudesse fazer uso, no Brasil, das liberdades individuais previstas pelo liberalismo (liberdade política, econômica e de pensamento). Quaresma podia, como indivíduo, movimentar-se pela sociedade para revelá-la e criticá-la.

\section{As ideias de Policarpo}

Quaresma encontra nos livros uma visão de país, pela qual se apaixona, e essa visão passa a valer para ele como realidade. A experiência de vida que deveria contribuir na formação das ideias, não influi significativamente, a não ser, de maneira seletiva ou distorcida, 
para corroborar a ideologia nativista. Policarpo assimila dos livros, de sua biblioteca cuidadosamente selecionada, o ideário ufanista que havia sido a base do nacionalismo brasileiro desde a independência.

É possível que a personagem tenha tido modelos reais, em que o amor da nação estivesse trabalhado pelas circunstâncias e reduzido a esquema mais básico. Lima Barreto menciona numa crônica um amigo patriota, Juvenal Calheiros, "crente na grandeza do Brasil, nas suas riquezas e no seu futuro.” (BARRETO, 2004, p. 222). Em linhas básicas, está aí o patriotismo de Policarpo na vida real. É uma visão afetiva da nação, mas está longe de constituir um programa de ação.

O nacionalismo não era a única ideologia que orientava Policarpo. O sentimento nacional plasmado no Romantismo era predominantemente contemplativo, uma ideologia da paisagem (FIGUEIREDO, 1998, p. 27-31). Seria a influência do positivismo, do qual se havia filtrado um racionalismo confiante, que indicaria a possibilidade ou a necessidade da ação no romance. ${ }^{4}$ Em Policarpo, o amor à pátria associa-se a uma certeza "positiva" no progresso do país, que pode permitir seu deslocamento da exaltação contemplativa da natureza a um projeto de reformas em vários campos. ${ }^{5}$ A forma racionalizada de atuar por "áreas" cobre os segmentos autonomizados na sociedade burguesa: a cultura, a economia, a política. $\mathrm{O}$ conteúdo do nacionalismo ufanista de Policarpo ganha com isso um enfoque e um método de ação. Dava orgulho que o rio Amazonas fosse o maior do mundo, mas também era necessário adotar medidas que o tornassem mais navegável. Policarpo dramatiza com a própria figura o momento em que o nacionalismo contemplativo e ufanista abraça a ideia de grandes reformas.

4 "A forma de assimilação dessa doutrina [o positivismo] por um e outro [Lima e Euclides] foi muito diversa, como veremos, o que entretanto não impediu que alguns pressupostos mais gerais e a essência ética da doutrina viessem a formar um estrato básico na consciência de ambos, aflorando por toda parte em sua obra e animando o seu projeto político e cultural." (SEVCENKO, 1985, p. 121).

${ }^{5}$ No romance que publicara anteriormente, Isaías faz o seguinte comentário sobre o positivismo de Teixeira Mendes: "ficava assombrado com a firmeza com que ele anunciava a felicidade contida no positivismo e a simplicidade dos meios necessários para a sua vitória: bastava tal medida, bastava essa outra - e todo aquele rígido sistema de regras, abrangendo todas as manifestações da vida coletiva e individual, passaria a governar, a modificar costumes, hábitos e tradições." (BARRETO, 1956a, p. 141142). Isaías descreve uma atitude bastante semelhante à de Quaresma, uma maneira inteiramente abstrata de conceber o mundo. 
[...] o major, depois de trinta anos de meditação patriótica, de estudos e reflexões, chegava agora ao período da frutificação. A conviç̧ão que sempre tivera de ser o Brasil o primeiro país do mundo e o seu grande amor à Pátria, eram agora ativos e impeliram-no a grandes cometimentos. Ele sentia dentro de si impulsos imperiosos de agir, de obrar e de concretizar as suas ideias. (BARRETO, 1956b, p. 45$)^{6}$

Com algumas poucas reformas, igualar e até superar as nações desenvolvidas seria uma questão de tempo: "pequenos melhoramentos, simples toques, porque em si mesma (era a sua opinião), a grande pátria do Cruzeiro só precisava de tempo para ser superior à Inglaterra." (BARRETO, 1956b, p. 45). ${ }^{7}$

Mas isso ainda não explica a saída de Policarpo para a ação. Para Sérgio Buarque, o positivismo no Brasil havia sido uma ideologia de gabinete, livresca e, paradoxalmente, mais negativa que positiva. A confiança que tinham os positivistas no poder milagroso das ideias não seria uma forma de rejeição da realidade do país? Eles correspondiam a um tipo de intelectual bastante comum em terras brasileiras, que encontrava na "crença mágica no poder das ideias" uma forma digna de evasão da realidade (HOLANDA, 1995, p. 158-159).

A certeza abstrata que Sérgio Buarque descreve nos positivistas é do mesmo tipo da que encontramos em Policarpo:

É realmente edificante a certeza que punham aqueles homens no triunfo final das novas ideias. O mundo acabaria irrevogavelmente por aceitá-las, só porque eram racionais, só porque a sua perfeição não podia ser posta em dúvida e se impunha obrigatoriamente a todos os homens de boa vontade e de bom senso. [...] E nossa história, nossa

\footnotetext{
${ }^{6}$ Seria possível identificar o período em que o nacionalismo de Policarpo se torna ativo com a implantação do regime republicano, uma vez que o final do romance, com o fuzilamento de Policarpo, se situa historicamente na Revolta da Armada, vencida em março de 1894 pelo Marechal Floriano Peixoto.

${ }^{7}$ Paulo Arantes (1988) considera que o etapismo positivista serviu bem às elites intelectuais como uma ideologia de compensação e acomodação com o atraso brasileiro. As relações sociais atrasadas não eram "problemáticas", pois constituíam uma etapa do percurso que levava ao progresso.
} 
tradição eram recriadas de acordo com esses princípios inflexíveis. (HOLANDA, 1995, p. 158)

Se trocarmos "as novas ideias" pelo "nacionalismo ufanista", encontramos aí nosso herói. Até as virtudes que Sérgio Buarque aponta nos positivistas ortodoxos ("probidade, sinceridade, desinteresse pessoal") são as mesmas que Lima Barreto atribui a Policarpo. Se, em termos práticos, as certezas positivistas favorecem a evasão e não a ação dos intelectuais e se, mesmo em termos teóricos, o grande agente do positivismo não são os indivíduos livres, nem os cidadãos, mas o Estado, então a iniciativa de agir por conta própria, sozinho, para tornar realidade as potencialidades do país, vai ancorar-se noutra orientação ideológica. O que leva Policarpo diretamente à ação é um individualismo liberal.

Individualismo e confiança numa razão universal, além, é claro, das visões nacionalistas, levam Policarpo a enviar o requerimento do tupi ao Congresso. São convicções tão profundas que ele não consegue compreender depois por que é ridicularizado. Do ponto de vista de seu objetivo, a emancipação cultural da nação, a proposta era inteiramente coerente. Todos deveriam ver da mesma forma. Então a razão não era a mesma para todos? Se era correta, pouco importavam as dificuldades concretas e o impacto de proporções revolucionárias da implantação de uma medida como essa. A reforma necessária, baseada na razão e no estudo, devia impor-se a todas as consciências e obstáculos. Aqui a iniciativa individual de se dirigir ao congresso, como um "cidadão brasileiro", "usando do direito que lhe confere a Constituição", marca o traço liberal da ação de Policarpo. Mas a ideia de uma reforma radical a ser implantada de cima para baixo, por decreto, aproxima-o do positivismo.

As tentativas na agricultura ressaltam mais uma vez o racionalismo abstrato de Policarpo. Pressupondo as terras férteis e munindo-se de conhecimento técnico, ele pensava em ser um pioneiro, uma espécie de Robinson Crusoe da agricultura brasileira. Mirando-se em seu exemplo, mais um e mais outro o acompanhariam, até revolucionar o campo. Essa era sua expectativa inicial, antes que viesse a se dar conta de que a atividade econômica do país era um sistema bem armado, cheio de interesses, contra o qual seu individualismo econômico iria se quebrar. A área da política é aquela em que Quaresma mais se aproxima do positivismo, na figura do sábio que entrega seu projeto de reformas ao ditador republicano, em quem abstratamente vê "Sully e Henrique IV" (BARRETO, 1956b, p. 185). 
Sobre a base de um pensamento rigorosamente abstrato, Policarpo reúne em si um complexo muito próprio em que se combinam de várias formas ideologias de prestígio: o individualismo liberal (baseado na excentricidade, mas com certas condições de partida); o ufanismo, em que a natureza dá a base da afetividade nacionalista; e o positivismo, com sua parte de racionalismo evolucionista e sistematizador.

\section{Uma liberdade inútil}

Policarpo só vem a encontrar a sociedade quando se dispõe a transformá-la. Não a conhece antes, instruindo-se de seus controles gradativamente e assimilando aos poucos as relações acomodatícias, ao ponto de se adaptar. Os primeiros contatos já são confrontos, não porque Policarpo tivesse uma intenção de combate, mas porque havia um desencontro enorme entre suas ideias e a realidade.

A ação do romance, como disse antes, separa as tarefas por grandes áreas: a cultura, a economia, a política. Depois de muito estudo, Policarpo não tinha mais dúvidas acerca da grandeza natural de seu país, mas não estava inteiramente certo da "originalidade de costumes e usanças". Seria preciso intervir para promover uma esfera cultural própria e original. A leitura de historiadores, cronistas e filósofos levam-no à modinha, acompanhada do violão, como "a expressão poético-musical característica da alma nacional" (BARRETO, 1956b, p. 37-38).

O romance começa com o episódio da aula de violão. Policarpo quer disciplinar e transformar a modinha em motivo original de arte e, para isso, contrata como professor um conhecido seresteiro, Ricardo Coração dos Outros. Adelaide, sua irmã, censura-o por se meter com semelhantes companhias ("um quase capadócio") e a entrada do violão na casa, um instrumento popular e pouco distinto, lhe diminuíra um pouco a consideração na vizinhança. Policarpo não dá ouvidos a Adelaide e sequer percebe os prejuízos causados à sua reputação. Ele confia apenas em si mesmo e no seu projeto. As opiniões dos outros, os preconceitos sociais não influem no que ele pensa e faz.

A ironia do narrador, nesse episódio, mostra que ele não segue o entusiasmo de sua personagem, antes se distancia dela. ${ }^{8}$ As modinhas

\footnotetext{
${ }^{8}$ Para Oakley (2011, p. 101-105), a base ideológica sistemática da sátira no romance demonstraria uma orientação spenceriana, principalmente em sua aversão a uma
} 
aparecem como algo artificial e já convencionalizado. O desejo de elevação delas se justificava mais pelo palavreado, pelos exemplos históricos do trânsito que tiveram em camadas sociais mais altas no estrangeiro do que pela relação com o Brasil propriamente. A tentativa fracassa porque o major não consegue aprender a tocá-las; é muito rígido, não tem o "dengue" para sentir e acercar-se do instrumento. As modinhas continuam mesmo no seu papel de divertimento popular e ganham uma pequena voga na classe média do subúrbio.

Incapaz de conectar uma tradição original e a arte erudita brasileira, Policarpo se volta para os costumes. As festas e folguedos tradicionais deviam ser praticados; era preciso trazê-los direto da memória popular e reavivar os costumes. Com esse intuito, Quaresma e seu vizinho general, que era do Norte e via nas festas oportunidade de casar as filhas, vão visitar numa localidade afastada uma senhora negra, ex-lavadeira da casa do militar, para que lhes ensinasse antigos usos e canções. Antes mesmo da chegada deles, o narrador prepara a desilusão. Pelo caminho onde passara o rei D. João VI, vindo de Portugal, aponta que não havia vestígios do acontecimento tão significativo para a história brasileira. Da mesma forma, na memória da velha senhora, não restam lembranças das antigas canções. Paira sobre tudo o veredito do narrador: "Entre nós tudo é inconsistente, provisório, não dura." (BARRETO, 1956b, p. 48).

Mas Policarpo não desiste. Se a memória não havia sido guardada pelo povo, ainda existia a opção dos colecionadores e folcloristas. Junto com o general Albernaz, ele vai em busca de um velho poeta, que colecionava e publicava "coleções que ninguém lia, de contos, canções, adágios e ditados populares." (BARRETO, 1956b, p. 52). Das pastas do folclorista saem várias anedotas, fábulas e o narrador, sempre irônico e distanciado, registra algo de paternalista e condescendente no entusiasmo do colecionador. Policarpo e Albernaz trazem da visita a sugestão de um festejo - o tangolomango -, que Policarpo executa numa festa e o faz desmaiar de cansaço no final, derrotado pelo esforço. Para seu maior

\footnotetext{
"sociedade militar". O argumento é interessante, mas não se encontram no romance argumentos em favor de uma "sociedade industrial" competitiva, que é a alternativa de Spencer ao militarismo. O herói barretiano, como assinala o mesmo crítico, segue o modelo de Carlyle: é sincero, desinteressado e comprometido com a verdade (OAKLEY, 2001, p. 105-106).
} 
desapontamento, vem a saber depois que o festejo era estrangeiro. A cultura que busca como raiz lhe escapa. Encontra no máximo peças esparsas, sem a grandiosidade e a originalidade requeridas pela Pátria. A grandeza do país contrastava com sua precariedade cultural. ${ }^{9}$

Insatisfeito, mas não vencido em sua obsessão patriótica, Policarpo recorre às culturas primitivas em busca da originalidade brasileira. Ele organiza um sistema de cerimônias e festas baseado nos costumes dos índios, contemplando todas as relações sociais. A proposta era uma reforma cultural completa, em substituição à cultura europeia. ${ }^{10}$ Seguindo o tal sistema, Policarpo recebe um dia o compadre e a afilhada em casa chorando e arrancando os cabelos. Esse costume de apertar a mão, explica Policarpo, não era nosso. Deveríamos chorar quando encontrávamos os amigos, como faziam os tupinambás (BARRETO, 1956b, p. 55-56). A perplexidade que desperta em todos desencoraja a medida. E Policarpo atina nesse meio tempo com algo que significaria mudança mais profunda, a exemplo da restauração da língua provençal empreendida por Frédéric Mistral, escritor e lexicógrafo francês.

As meditações e estudos de Policarpo a respeito da língua conduzem-no a medidas ainda mais radicais, que extrapolam o âmbito literário e filológico. Quando Policarpo envia requerimento ao Congresso, solicitando a mudança da língua oficial do país para o tupi-guarani, ele deixa o círculo doméstico e a estreita sociabilidade da vizinhança de subúrbio. O âmbito de ação se alarga, estendendo-se até o centro da vida política. A resposta ao seu gesto vem revelar duramente para Quaresma a separação que existe entre ele e seus compatriotas. Do Congresso, o teor do documento passa para a imprensa, de modo que, de uma hora para outra, a cidade inteira zomba do pedido. Apresenta-se no romance uma espécie de "esfera pública", que coíbe as pretensões racionalistas e individualistas do major.

\footnotetext{
${ }^{9}$ Uma crônica de Lima Barreto, ainda de 1903, já registrava esse pessimismo: "No Brasil tudo é grande, assegurava Tobias Barreto, exceto o homem, o que ele corroborava com a imagem feliz que bem parecíamos um moço com cabelos brancos." (BARRETO, 2004, p. 62).

${ }^{10}$ Sérgio Buarque (1995, p. 160) diz que os positivistas foram os exemplares mais acabados da forma de pensar típica de nossa intelectualidade: "Trouxemos de terras estranhas um sistema acabado e complexo de preceitos, sem saber até que ponto se ajustam às condições da vida brasileira e sem cogitar das mudanças que tais condições lhe imporiam." Nesse episódio, Lima Barreto satiriza tanto os ufanistas quanto os positivistas e ainda a mistura dos dois.
} 
A repartição reage não com zombaria, mas com hostilidade, delimitando o espaço do funcionário burocrático e corrigindo a liberdade imaginada por Quaresma. Os colegas não lhe perdoam a súbita notoriedade, a superioridade nascida fora dos meios burocráticos:

É como se visse no portador da superioridade um traidor
à mediocridade, ao anonimato papeleiro. Não há só
uma questão de promoção, de interesse pecuniário; há
uma questão de amor-próprio, de sentimentos feridos,
vendo aquele colega, aquele galé como eles, sujeito aos
regulamentos, aos caprichos dos chefes, às olhadelas
superiores dos ministros, com mais títulos à consideração,
com algum direito a infringir as regras e os preceitos.
(BARRETO, 1956b, p. 84)

Policarpo é medido pelos colegas. Ele se imaginava vivendo na sociedade de indivíduos iguais e comprometidos com a pátria, no sistema político que igualava a todos como cidadãos perante a constituição. Imaginava ainda que as ideias eram avaliadas unicamente em função de sua coerência, como um exercício de lógica, sem relação com a sociedade. A dinâmica própria da repartição recoloca Policarpo no meio social. Os colegas veem a proposta de uma nova ordem não como iniciativa cidadã, mas como transgressão. O individualismo excêntrico de Quaresma é pensado pelos colegas como afirmação da "personalidade", nos termos que Sérgio Buarque de Holanda descreveria duas décadas depois (HOLANDA, 1995, p. 155-157). Os colegas de Quaresma, que tinham de se submeter aos regulamentos e caprichos dos chefes, detestaram que ele, enviando um projeto ao Congresso, se sentisse "com algum direito a infringir as regras e os preceitos", ou seja, com direito a criticar e a querer mudar as coisas. Um "galé como eles" não tinha essa prerrogativa e Policarpo não estava numa sociedade abstrata de homens iguais ou numa república de cidadãos. Prerrogativas de classe, portanto, normalizavam a excentricidade (ou o capricho?) e a saída da ordem. Roberto Schwarz (1998) já identificara tais prerrogativas nas transgressões do narrador machadiano.

A cada investida de Quaresma, portanto, avultam as relações sociais que o indivíduo abstrato, a bem de sua autonomia, subestima ou desconhece. Mas Quaresma permanece cego a essas demonstrações. Por enquanto, não é a rede de relações sociais que o impede, mas "os inimigos terríveis, cujos nomes o seu delírio não chegava a criar." 
(BARRETO, 1956b, p. 97). Depois de mais algumas trapalhadas com o tupi na repartição e de uma interpelação furiosa do chefe, Policarpo perde o equilíbrio psicológico e vai parar no hospício.

Quando sai do hospital, Policarpo está abatido e melancólico, vive enclausurado em casa. Olga lhe sugere então ir morar no campo, ideia que ele acolhe com entusiasmo. Era um velho desejo seu, para o qual tinha inclusive projetos. A mania patriótica se reativa. Ele vende a casa na cidade e muda-se para um sítio no interior, a duas horas do Rio de Janeiro. Ali, vai tentar revolucionar a agricultura do país. Como de costume, está informado de todas as técnicas e instrumentos, mas o modelo é inadequado, não leva em consideração as dificuldades próprias da terra. Há um primeiro período, muito árduo, de adaptação do funcionário público à vida de agricultor. Até porque, como das outras vezes, Quaresma se lança ele mesmo ao trabalho, inicialmente apenas com a ajuda do agregado e empregado negro Anastácio.

Todas as dificuldades que a terra podia oferecer, Quaresma enfrenta e vence, como as formigas, as pragas, as pestes. Mesmo as agruras do comércio, a falta de lucro e incentivos não são suficientes para derrotá-lo. Mas, das intrigas políticas, ele não passa. Já ressabiado pelos episódios da cidade, Policarpo tenta fugir da política local, até porque se resume a arranjos. Mas em vão. Ao despedir sem apoio as duas partes em disputa, atrai o ódio e a vingança de ambas, que encontram nas leis do Estado e do Município formas de paralisar sua atividade.

As dificuldades da atividade rural e a política local recortam um espaço social para o indivíduo abstrato, que queria ser uma espécie de pioneiro. Registre-se que a ação de Policarpo, produtor de classe média, não alcança os agricultores pobres. Não é por meio dele que aparecem as dificuldades próprias dos camponeses. Até o narrador abre mão da onisciência e deixa que eles mesmos digam quais são seus problemas. O romance apresenta uma conversa de Olga com Felizardo, que explica a ela porque não cultivam as terras improdutivas em volta: "Terra não é nossa..." (BARRETO, 1956b, p. 163).

A concentração da propriedade, a expropriação do homem do campo e a falta de apoio governamental traduzem-se em pasmaceira e imprevidência. Quaresma percebe na prática as relações de poder que garantem o status quo e atravancam o progresso econômico da nação. Pensa que havia sido ingênuo com suas tentativas na modinha, no tupi, no folclore. As mudanças tinham de ser mais profundas, era preciso 
refazer o sistema político-administrativo. Imaginou "um governo forte, até à tirania" (BARRETO, 1956b, p. 185). Na ocasião, acontece a Revolta da Armada e Policarpo apresenta-se como voluntário na resistência organizada pelo Marechal Floriano Peixoto, para defender e consolidar a República.

Policarpo acredita nesse momento que as reformas teriam de ser impostas pela força. O indivíduo livre, que sonhava em ser um reformador e um exemplo, desespera de suas possibilidades, aliena sua liberdade e entrega seu projeto - seu memorial de reformas - para a ação do grande líder. Nesse episódio, Policarpo encontra-se com os positivistas militares, que o romance irá condenar veementemente pelo fetichismo e pela arrogância.

Mas o que Policarpo esperava achar na guerra? A determinação, a grandiosidade que não achara em lugar algum? Decepciona-se novamente. Não eram projetos, ideias e ações revolucionárias que estavam em jogo. Na verdade, a guerra resumia-se a "fogo para diante", como dizia o arrogante Fontes, subalterno de Policarpo no batalhão. A convicção republicana não tinha raízes profundas, era um fetiche. A grande maioria, mesmo entre os revoltosos, sequer sabia por que matava e morria, estava ali pelo hábito de obedecer. E o líder, o grande líder, não era mais que o prolongamento, a expressão desoladora de tudo que ele encontrara até aquele momento:

O bigode caído; o lábio inferior pendente e mole a que se agarrava uma grande "mosca"; os traços flácidos e grosseiros; não havia nem o desenho do queixo ou olhar que fosse próprio, que revelasse algum dote superior. Era um olhar mortiço, redondo, pobre de expressões, a não ser de tristeza que não lhe era individual, mas nativa, de raça; e todo ele era gelatinoso - parecia não ter nervos. (BARRETO, 1956b, p. 208-209)

Não havia nada na aparência de Floriano que figurasse uma expressão individual. Policarpo descobrira que o indivíduo comum não tinha poder para mudar as coisas, mas jogara suas expectativas noutro tipo de indivíduo: o tirano com poderes excepcionais, rigorosamente diferente da comunidade que o formara. A esperança de Policarpo no indivíduo trouxera-o do requerimento ao Congresso ao apoio à ditadura republicana. Ele queria que Floriano fosse um indivíduo extraordinário, uma espécie de Sully, mas descobre no ditador nada mais que a "personalidade" do familismo brasileiro. "A sua concepção de governo não era o despotismo, nem a democracia, nem a aristocracia; era a de uma tirania doméstica." (BARRETO, 1956b, p. 212). 
Enquanto Policarpo oferece voluntariamente a vida, Floriano sequer dá atenção a seu memorial. Não por discordar, mas por indiferença. ${ }^{11} \mathrm{E}$ quando um Policarpo horrorizado protesta, em carta ao marechal, pela execução sumária dos prisioneiros de guerra, é ele mesmo preso, sem direito a sequer ser informado do motivo.

$\mathrm{Na}$ prisão, atordoado e sozinho, Policarpo faz o movimento negativo completo: "A pátria que quisera ter era um mito." (BARRETO, $1956 b$, p. 284). Volta-se então para si mesmo, pergunta-se por que não tinha ido viver em paz, casar e ter filhos como todo o mundo. No momento seguinte, resiste ao desespero, pensa que não teria sido em vão se houvesse outros que continuassem a lutar. E desanima porque não vê saída. Policarpo é fuzilado e encena a falta de horizonte histórico do seu desejo de mudanças. $\mathrm{O}$ fecho do romance arrisca um vago olhar adiante, baseado na historicidade das coisas humanas. O passado traz a memória de lutas e desolações, mas também de orgulho e bravura. O presente é desesperador, mas há sempre os que lutam. "Esperemos mais", diz por meio de Olga (BARRETO, 1956b, p. 297).

Recapitulando, acompanhamos um Policarpo com muitas possibilidades de agir. Ele tenta aprender violão, contra os preconceitos da época; é solitário, mas tem inserção social suficiente para propor festas e realizá-las; pode enviar um requerimento ao congresso; pode comprar um sítio para fazer suas experiências em agricultura; pode arcar com as condições desvantajosas na negociação de seus excedentes; pode negar-se a compactuar com os ajustes políticos, ainda que sofra as consequências; pode largar tudo e apresentar-se como voluntário no exército; tem acesso ao homem mais poderoso da nação, o marechal Floriano, para lhe entregar um projeto; pode enviar carta de protesto, mantendo-se coerente até o fim aos seus valores.

11 “[...] a expressão-chave indiferentismo dava então a volta no pequeno mundo de nossas elites, acabrunhadas pelo caráter 'amorfo e dissolvido' (outra expressão de época) do povo brasileiro, graúdos e miúdos arrastados juntos no mesmo 'torvelinho da indiferença', sem embargo dos primeiros levarem vida muito boa." (ARANTES, 1988, p. 188). O trecho refere-se ao período ainda imperial e escravocrata, mas pode ser estendido sem anacronismo à Primeira República. $\mathrm{O}$ episódio com a agricultura no romance desmistifica a "indiferença" das populações rurais e denuncia as relações de opressão no campo: latifúndio, coronelismo e abandono dos pequenos pelo poder público. 
Policarpo tem chance de agir, percorrendo o caminho aberto pelo liberalismo burguês. Sua posição abstrata de indivíduo autônomo é garantida o máximo possível pelo autor, considerando as condições brasileiras, e reforçada com certas características de personalidade: introspecção, tenacidade, sensibilidade, boa índole. Toda essa liberdade, entretanto, vai sendo corroída pela impotência, à medida que a narrativa avança. As razoáveis possibilidades de agir aparecem confrontadas com sua impossibilidade de mudar o que quer que seja. Mecanismos de coerção social apresentam-se em amplo leque, desde a exposição ao ridículo até o fuzilamento. Arede de relações sociais se completa e todos os impedimentos funcionam dentro dela. Os indivíduos, se é que existem, são impotentes e terminam por entregar (inutilmente) seus projetos aos ditadores. $\mathrm{O}$ individualismo, como forma de olhar para a complexidade social e a duração histórica, leva o indivíduo a um impasse e a um beco sem saída.

O percurso em busca da nação, com a passagem obsessiva de uma tentativa a outra, revela a Policarpo e ao leitor que não existe no Brasil uma nação formada sobre a base de um projeto coletivo. É essa falta de liames coletivos - em que pese o funcionamento de todas as instituições -, que explica no romance desde por que as pessoas do povo esqueceram suas histórias, os camponeses vivem miseráveis ao lado de terras improdutivas, até porque os soldados lutam alienados na guerra e podem ser fuzilados sumariamente, a mando de um tirano no governo.

É digno de nota também que os muito ricos não sejam incluídos nos planos de reforma de Policarpo. O romance é uma exploração das possibilidades de mudança a partir da classe média. Mas a ausência das elites também dá a pensar que nem o ingênuo Policarpo teria a ilusão de que elas seriam atores num projeto nacional, coletivamente construído.

\section{Referências Bibliográficas}

ARANTES, P. E. O positivismo no Brasil. Novos Estudos, CEBRAP. São Paulo, n. 21, p. 185-194, julho de 1988.

BARBOSA, F. A. A vida de Lima Barreto. 7. ed. Belo Horizonte: Itatiaia; São Paulo: Editora da Universidade de São Paulo, 1988.

BARRETO, L. Recordações do escrivão Isaías Caminha. São Paulo: Editora Brasiliense, 1956a. [Obras Completas de Lima Barreto, v. I].

. Triste fim de Policarpo Quaresma. São Paulo: Editora 
Brasiliense, 1956b. [Obras Completas de Lima Barreto, v. II].

. Vida e morte de M. J. Gonzaga de Sá. São Paulo: Editora Brasiliense, 1956c. [Obras Completas de Lima Barreto, v. IV].

. Toda crônica. Rio de Janeiro: Agir, 2004. v. I.

CANDIDO, A. Formação da literatura brasileira: momentos decisivos. 11. ed. Rio de Janeiro: Ouro sobre Azul, 2007.

DUMONT, L. O individualismo: uma perspectiva antropológica da ideologia moderna. Trad. Álvaro Cabral. Rio de Janeiro: Rocco, 1985.

FIGUEIREDO, C. L. N. Trincheiras de sonho: ficção e cultura em Lima Barreto. Rio de Janeiro: Tempo Brasileiro, 1998.

GOLDMANN, L. A sociologia do romance. Trad. Álvaro Cabral. 3. ed. Rio de Janeiro: Paz e Terra, 1976.

HOLANDA, S. B. Raízes do Brasil. 26. ed. São Paulo: Companhia das Letras, 1995.

OAKLEY, R. J. Lima Barreto e o destino da literatura. São Paulo: UNESP, 2011.

PEREIRA, L. M. História da literatura brasileira: prosa de ficção (de 1870 a 1920). Belo Horizonte: Itatiaia; São Paulo: EDUSP, 1988.

SCHWARZ, R. Ao vencedor as batatas. São Paulo: Duas Cidades; Ed. 34, 2000.

ed. São Paulo: Duas Cidades, 1998.

SEVCENKO, N. Literatura como missão: tensões sociais e criação cultural na Primeira República. 2. ed. São Paulo: Brasiliense, 1985.

WATT, I. A ascensão do romance. Trad. Hildegard Feist. São Paulo: Companhia das Letras, 1990. 
